9. Martunovskyy S. V. Эkonomycheskaya nauka ot Arystotelya do nashykh dney: Osnovnue napravlenyya analyza / S. V. Martonovskyy. - Odessa : Druk, 2001.-192 s.

10. Marshall A. Pryntsypы эkonomycheskoy nauky : v 3 t. / A. Marshall. -M. : Prohress : Unyvers, 1993. - T. I - III.

11. Nesenenko P. P. Heneza metodolohiyi klasychnoho ekonomichnoho napryamu ta keynsianstva: navchal'nyy posibnyk / P. P. Nesenenko, O. A. Artemenko. - Odesa : ONEU, FOP Hulyayeva V. M., 2018. - $262 \mathrm{~s}$.

12. Rykardo D. Nachala polytycheskoy эkonomyy y nalohovoho oblozhenyya / D. Rykardo / Antolohyya эkonomycheskoy klassyky. Predyslovye Y. A. Stolyarova. - M. : MP «ЭKONOV», «KLYuCh», 1993. - $475 \mathrm{~s}$.

13. Smyt A. Yssledovanye o pryrode y prychynakh bohat·stva narodov/ A. Smyt / Antolohyya эkonomycheskoy klassyky. Predyslovye Y. A. Stolyarova. - M. : MP «ЭKONOV», «KLYuCh», 1993. - 475 s.

14. Sэy Zh. B. Traktat polytycheskoy эkonomyy / Zh. B. Sэу. - M. : yzd. K. T . Soldatenkova, 1896. - 112 s.

18.09.2018

УДК 658.821:005.52

JEL Classification: M490

Popovskyi Yurii, Kerekesha Olga

\title{
THEORETICAL ASPECTS OF STRATEGIC ANALYSIS OF ENTERPRISES COMPETITIVENESS
}

Theoretical aspects of the strategic analysis of the enterprises competitiveness are a component of an unified organic system of theoretical and methodological foundations of strategic analysis, which correspond to modern scientific concepts, the realities of the business environment and the practical needs of the economic entities functioning. Reducing the degree of uncertainty and being the basis 
for the adoption of well-grounded management decisions, strategic analysis provides the development of recommendations for achieving the strategic goals of the business entity in the specific conditions of its functioning, ensures effective implementation of the organization's development strategy, and also increases the efficiency and effectiveness of the business. The well-grounded and competently implemented strategy of an enterprise allows to neutralize or minimize risks, to effectively use the opportunities provided, to develop the growth potential, to reduce the negative effects of threats and to transform the weaknesses into advantages, to manage resources efficiently and, on this basis, to increase the manageability, efficiency and real impact of business in the long run.

In the conditions of modern realities of Ukrainian business, the relevance of the issues of strategic analysis as an integral instrument of an effective, balanced and truly active strategic management of enterprises is steadily increasing. The prerequisites for increasing the relevance of strategic analysis in relation to companies are different in nature and etymology.

An increasing number of the most advanced progressive managers of enterprises are aware of the truly urgent need to develop a strategy, implement strategic management, and actively apply the methodology and tools of strategic analysis in the process of substantiating and evaluating strategic management decisions. In this regard, the construction, implementation and practical implementation of the potential of an effective model of information and analytical support for strategic management are indispensable conditions for the prosperity of each enterprise in modern conditions.

Key words: development tendencies, competitiveness, strategy, competition, strategic management, management decisions, strategic goals.

Поповський Юрій, Керекеша Ольга

\section{ТЕОРЕТИЧНІ АСПЕКТИ СТРАТЕГІЧНОГО АНАЛІЗУ КОНКУРЕНТОСПРОМОЖНОСТІ ПІДПРИЕМСТВ}

Теоретичні аспекти стратегічного аналізу конкурентоспроможності підприємств є складовою єдиної органічної 
системи теоретико-методичних основ стратегічного аналізу, які відповідають сучасним науковим уявленням, реаліям ділового навколишнього середовища i практичних потреб функціонування підприємств. Стратегічний аналіз, знижуючи ступінь невизначеності і будучи основою прийняття всебічно обгрунтованих управлінських рішень, забезпечує вироблення рекомендацій для досягнення стратегічних цілей підприємства в конкретних умовах його функціонування, забезпечує ефективну реалізацію стратегії розвитку організації, а також підвищує ефективність та результативність бізнесу.

Обгрунтована i грамотно реалізована стратегія підприємства дозволяє нейтралізувати або мінімізувати ризики, ефективно використовувати надані можливості, розвивати зростання потенціалу, знижувати негативний ефект загроз і трансформувати слабкі сторони в переваги, раціонально розпорядитися наявними ресурсами і на цій основі підвищити керованість, ефективність і реальну результативність бізнесу в довгостроковій перспективі.

В умовах сучасних реалій українського бізнесу актуальність проблематики стратегічного аналізу як невід'ємного інструменту ефективного, зваженого та дійсно працюючого стратегічного управління підприємствами неухильно зростає. Передумови актуалізації стратегічного аналізу по відношенню до компаній мають різний характер і етимологію. Все більшу кількість найбільш сучасних прогресивно мислячих керівників підприємств усвідомлюють справді нагальну потребу в розробці стратегії, реалізації стратегічного менеджменту та активному застосуванні методики та інструментів стратегічного аналізу в процесі обгрунтування та оцінки стратегічних управлінських рішень. У зв'язку з цим побудова, впровадження і практична реалізація потенціалу ефективної моделі інформаційноаналітичного забезпечення стратегічного управління виступають неодмінними умовами процвітання кожного підприємства в сучасних умовах.

Ключові слова: тенденції розвитку, стратегія, конкурентоспроможність, конкуренція, стратегічне управління, стратегічні цілі, управлінські рішення. 


\section{ТЕОРЕТИЧЕСКИЕ АСПЕКТЫ СТРАТЕГИЧЕСКОГО АНАЛИЗА КОНКУРЕНТОСПОСОБНОСТИ ПРЕДПРИЯТИЙ}

Теоретические аспекты стратегического анализа конкурентоспособности предприятий являются составляющей единой органичной системы теоретико-методических основ стратегического анализа, которые соответствуют современным научным представлениям, реалиям деловой окружающей среды и практических нужд функционирования предприятий. Стратегический анализ, понижая степень неопределённости и будучи основой принятия всесторонне обоснованных управленческих решений, обеспечивает разработку рекомендаций для достижения стратегических целей предприятия в конкретных условиях его функционирования, обеспечивает эффективную реализацию стратегии развития предприятия, a также повышает эффективность и результативность бизнеса.

Обоснована и грамотно реализована стратегия предприятия позволяет нейтрализовать или минимизировать риски, эффективно использовать предоставленные возможности, развивать рост потенциала, снижать негативный эффект угроз и трансформировать слабые стороны в преимущества, рационально распорядиться имеющимися ресурсами и на этой основе повысить управляемость, эффективность и реальную результативность бизнеса в долгосрочной перспективе.

В условиях современных реалий украинского бизнеса актуальность проблематики стратегического анализа как неотъемлемого инструмента эффективного, взвешенного и действительно работающего стратегического управления предприятиями неуклонно растет. Предпосылки актуализации стратегического анализа по отношению к компаниям имеют различный характер и этимологию.

Bce большее количество наиболее современных прогрессивно мыслящих руководителей предприятий осознают действительно насущную необходимость в разработке 
стратегии, реализации стратегического менеджмента и активном применении методики и инструментов стратегического анализа в процессе обоснования и оценки управленческих решений. В связи с этим построение, внедрение и практическая реализация потенциала эффективной модели информационноаналитического обеспечения стратегического управления выступают непременными условиями процветания каждого предприятия в современных условиях.

Ключевые слова: тенденции развития, стратегия, конкурентоспособность, конкуренция, стратегическое управление, стратегические цели, управленческие решения.

\section{DOI: 10.32680/2409-9260-2018-9(261)-146-162}

Researches and publications analysis of recent years. A number of works of both domestic scientists and scientists from other countries is devoted to the problem of constructing the concept of strategic analysis and competitiveness of enterprises. In particular, R.Grant, T.Ambler, Nuzhna O.A., Revutskaya N.V., Nemtsov V.D., Dovgan L.S. [1-5].

The purpose of the article is to theoretically generalize the concept of the basic provisions of the strategic analysis of enterprises' competitiveness.

Presentation of the main research material. R. Grant defined the role of strategic analysis as follows: "Regardless of whether the strategy formulation is formal or informal, whether strategies are well thought out or emergent (random), systematic analysis is a vital contribution to the strategic process. In the absence of analysis, strategic decisions are becoming a victim of the struggle for power, the desires of individuals and their inclination to wishful thinking" [1].

Considering the crucial importance of strategic analysis in the system of strategic management of the enterprise, the theoretical aspects of strategic analysis are closely related to both the basic concepts of financial management (preservation and increase of capital, cash flows, entrepreneurial risk), as well as with modern aspects of strategic accounting and strategic management, including: balanced scorecard, BSC, total performance scorecard (TPS), process 
management (PM), business performance management (BPM), value based management (VBM), Hoshin planning, tableau de bord methodology, efficiency prism [7].

When carrying out a strategic analysis of the enterprise's activities it is necessary to take into account its specificity, which is specified in number of aspects. The main ones among them, in our opinion, are the following features, schematically represented in the figure "1":

1. Form of ownership and organizational-legal form of the enterprise;

2. Type of enterprise (specialized or diversified);

3. Branch of the enterprise (seasonality of work);

4. Dimensions and organizational structure of the enterprise;

5. Existing control system at the enterprise.

Objects of strategic analysis can be: the strategy of enterprise development; strategic climate of the enterprise; strategic potential of the enterprise; strategic position of the enterprise; strategic alternatives; strategic performance indicators; strategic management decisions [4].

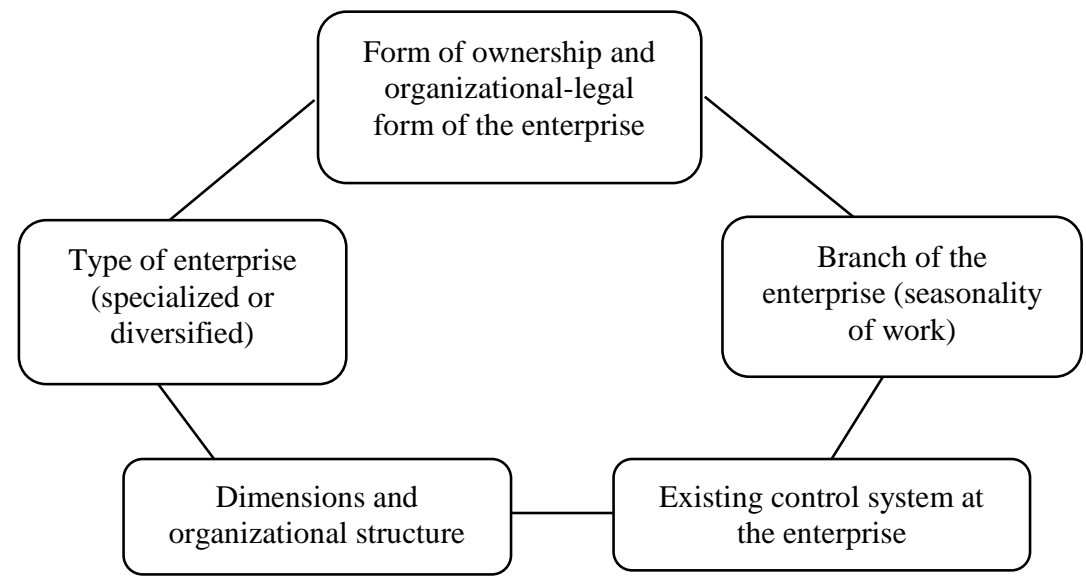

Figure 1. Features of the economic entity that need to be taken into account when conducting a strategic analysis

The strategy is a long-term, well-founded and quantitatively defined direction of enterprise development, concerning the sphere, 
form and sources of its activities, the system of relations within the enterprise, as well as the position of the enterprise in the environment that leads it to its goals. The emphasis on the need for formalizing the strategy assumes that the strategy is to be described with the help of target strategic indicators of activity, which is the basis for further evaluation of following the chosen strategy by enterprise, the compliance of the basic strategy in the constantly changing conditions of the external and internal business environment of the enterprise, as well as the degree of achievement of strategic goals, which are the basis of enterprise strategy [4].

An important method for assessing the competitiveness of enterprises is the strategic planning and management methodology, which is based on strategic balance (SWOT-analysis).

The SWOT method (translated from English - strength, weakness, opportunities, and threats) is based on an approach that allows you to explore together the external and internal environments of the enterprise. With this method, you can establish the relationships between the strength and weakness that are inherent in the enterprise, and external threats and opportunities. The main advantages of SWOT-analysis include: systematization of knowledge about internal and external factors influencing the process of strategic planning; definition of competitive advantages and formation of strategic priorities; periodic diagnostics of the market and resources of the firm [3].

V.D. Nemtsov and L.S. Dovgan distinguish a number of methodological approaches to assessing the competitiveness of the enterprise, which essentially differ in its essence and the basis of the formation of competitiveness indicators and, depending on the specifics of the industry and the specialization of the enterprise, their application is possible in different variations. These methods are: a method based on the theory of effective competition; approaches to the assessment of the competitiveness of the enterprise, which associate its level with the indicators of quality (competitiveness) of the manufactured products; methods based on the theory of competitive advantage; benchmarking method or competitive analysis method. [5]

This method determines the level of competitiveness by the following parameters: the share of the enterprise in the market; 
capital productivity; profitability of selling products; level of labor productivity; the share of the cost price of the manufactured product in the proceeds from its sale; price segment However, we believe that it is important to adapt this method to the specifics of enterprises, adding indicators that are important for the evaluation of their activities.

Evaluating the effectiveness of the enterprise, it is necessary to determine the influence of factors determining its competitiveness. According to the theory of effective competition, the most competitive enterprises are the enterprises with the best organized work of all units and services. Evaluation of the effectiveness of each unit involves an effectiveness evaluation of using the resource potential of the enterprise. According to O.A. Nuzhnoi, the method is based on the evaluation of four group indicators or competitiveness criteria [5].

The content of a strategic analysis is the study of the use of scientific methods of cognition of strategically important information about the functioning of a strategically oriented enterprise in order to make optimal management decisions. Taking into account the specifics of the objects of strategic analysis, its information base, along with the traditionally used financial information, including also significant non-financial data, in the aggregate providing the formation of the most holistic and objective representation of the investigated enterprise [1].

The subjects of strategic analysis are: financial analysts, financial and strategic managers of companies, external and internal auditors, arbitration managers, financial advisers [6].

An important subject of strategic analysis, in our opinion, can be the state represented by the financial authorities. Formed by the results of the strategic analysis, analytical information will be highly valuable for generating macroeconomic generalizations, developing forecasts, assessing the potential and prospects for development of the spheres of the economy, industries, regions and the state as a whole. When conducting a strategic analysis by external audit firms and independent auditors, it serves as an audit-related service [6].

In general, it should be noted that in recent years there has been an increase in the role and significance of the analytical component of audits. This is due to the expansion of the tasks solved 
by the auditors and the development of other services related to the audit work, first of all, consulting services, which involve intensification of the use of analytical procedures that enable us to understand the causes of the situation in the enterprise, in which the audit is held and evaluate the possibilities of its optimization, including the company's development strategy. [2]

At the same time, we would like to note that the analytical procedures used in the audit have certain specificity and are related to the detection and evaluation of the admissibility of certain deviations that do not cause significant inaccuracies, distorting the accounting statements and violating its reliability. In this regard, in our opinion, a clear demarcation line should be drawn between the strategic analysis and its analytical procedures, on the one hand, and the audit, on the other hand. The theoretical aspects of the strategic competitiveness analysis are presented in Figure 2.

An analysis of the strategic climate, strategic potential and strategic position of the enterprise allows us to implement a systematic and situational approach to assessing the nature and extent of the impact of external and internal factors of nterprise's strategic development.

The main objects of strategic analysis cover the strategic climate, the strategic potential and the strategic position of the enterprise and, together with them, the strategy of the enterprise that is developed and evaluated on the basis of their research, the strategic alternatives and strategic management decisions that are determined by them, as well as the strategic indicators describing them A strategic analysis process may be necessary and appropriate. The paramount importance of the strategic climate, the strategic potential determined within the framework of their joint consideration, as well as the development strategy of the organization, associated with their identification and consideration as priority objects of strategic analysis of the economic activities of enterprises.

The object of strategic analysis determines its targets, which are an integral list of the most important tasks of strategic analysis, which include: analyzing the strategic climate of an enterprise, analyzing the strategic potential of an enterprise, analyzing the strategic position of an enterprise, analyzing the strategy of an enterprise and evaluating the effectiveness of its implementation, 
analyzing strategic alternatives, analysis and monitoring of critical success factors and key business performance indicators. In accordance with the specified priority objects of strategic analysis, the main elements include:

1) analysis of the strategic climate, including an analysis of the overall business environment, and the specific business environment;

2) analysis of strategic potential, involving the analysis of resources, competencies, business processes and competitive advantages of the enterprise;

3) analysis of the strategic position, forming a generalizing assessment of the external and internal business environment of the actual or proposed strategy of the enterprise;

4) analysis of the enterprise strategy, including analytical substantiation of the strategy, strategic goals and strategic management decisions.

The development of the theoretical and methodological foundations of a strategic analysis of competitiveness is due to the objective requirements and prerequisites inherent in the emergence of any new branch of scientific knowledge, and also due to the fact that the relevant range of practical issues becomes important, independent and requires in-depth scientific study. Strategic analysis is an independent direction of analysis with its goals, objectives, functions, principles, and methods of analysis.

The idea of strategic analysis serves as a guiding principle in research activities and makes it possible to present this line of analysis as an integral system in the complex characteristic and logical interrelation of its elements.

But without an adequate goal building, the company will not be able to develop properly. The strategic goals can be defined as the main goals that influence the direction of development and the viability of the structure as a whole. Strategic goals should act as the main activity of the enterprise, leading to the fulfillment of its mission.

In this case, in our opinion, it is possible to distinguish two levels of the strategic goals of enterprises, these are private and general. 
Research and solving problems of generalization of terminology of strategic analysis, determination of its essence and content
Determining the role and place of strategic analysis in the system of strategic management

Methodological basis of strategic analysis

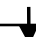

Identification of objects, subjects and characteristic features of strategic analysis of enterprises' competitiveness.

Justification of the concept of strategic analysis of enterprises' competitiveness on the basis of system, process, situational, balanced and strategic scientific approaches

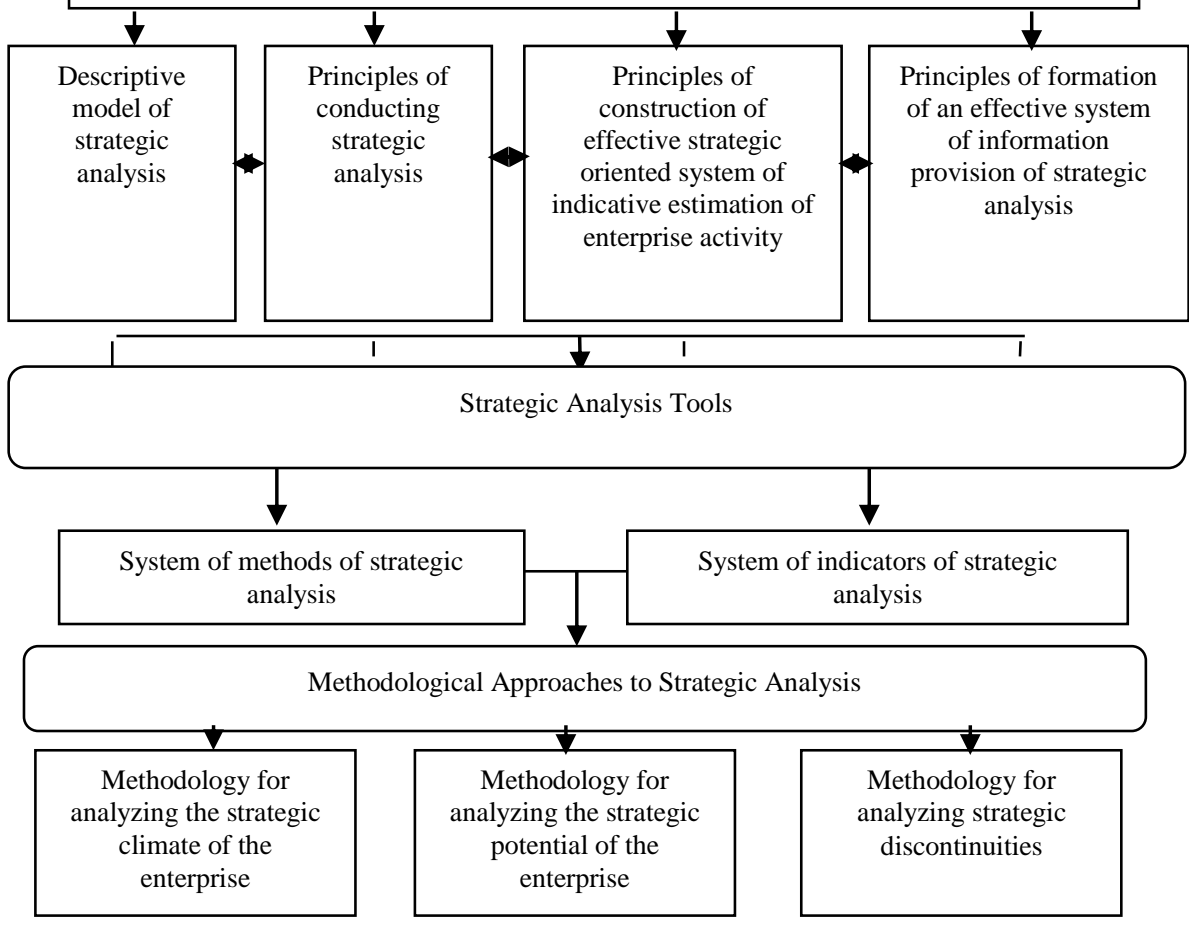


Figure 2. Theoretical aspects of strategic analysis of enterprises' competitiveness [Figure developed by the author]

The private strategic goals include the development of new products and the supply of new services, the creation of new and expansion of existing capacities, the introduction of new technologies, the training of personnel, the attraction of additional capital, the improvement of the organizational structure, the development of new markets, the increase in market shares and the creation of new distribution channels and etc.

The overall strategic objectives reflect the intentions of business owners and their senior management representatives regarding business development prospects and expected business results. Depending on this, strategic objectives can be: growth of the company's market value, increase in return on investment, balanced growth, stable profit, etc. So, if owners consider an enterprise as an asset for resale, then the strategic analysis will focus on a strategic indicator of the company's market value; if the company is one of the investment projects, then the strategic ROI (return on investment) will be analytically valuable; and if the company serves as the main source of income for the shareholders who work in it, then the central strategic indicator will be profit.

As the most important generalizing objects of strategic analysis, it is necessary to consider the scientific categories "strategic climate", "strategic potential" and "strategic position", reflecting the situational approach to assessment in the process of its conduct external and internal conditions of economic activity, taking into account their impact on the company's strategy.

The strategic climate is the state of the external business environment that influences the achievement of the organization's strategic goals; generalizing characteristic of the set of political, economic, social, technological and other factors external to the enterprise that determine the possibility, feasibility of implementation, as well as key parameters of the enterprise strategy.

Strategic potential is a measure of the ability and willingness of an enterprise to accomplish tasks that ensure the achievement of its strategic goals, that is, the internal potential for the implementation of an enterprise strategy. 
Strategic position - a characteristic that is determined by a joint analytical study of the internal and external business environment of the implementation of the strategy, that is, the strategic potential and strategic climate of the enterprise.

Analysis of the strategic climate, strategic potential and strategic position of the company allows implementing a systematic situational approach to assessing the nature and degree of influence of external and internal factors of the company's strategic development.

A strategic alternative is a variant of the development of events that may occur as a result of the adoption of certain strategic decisions.

In turn, it is possible to define strategic decisions as management-oriented decisions made in the framework of implementing or adjusting the adopted strategy of a company in order to achieve strategic success.

In the identification and selection of strategic alternatives, as well as in the evaluation of strategic management decisions, an important role is played by strategic analysis.

Reasonable and well-reasoned strategy of an enterprise allows neutralizing or minimizing risks, effectively using the opportunities provided and developing growth potential, reducing the negative effect of threats and transforming weaknesses into advantages, rationally managing available resources and, on this basis, improving long-term manageability and efficiency .

In this regard, the construction and practical realization of the potential of an effective model of information and analytical support for strategic management are indispensable conditions for the prosperity of each company. And if the essence of the strategy is "to build a position strong enough (and flexible enough) for an organization to achieve its goals despite all unforeseen interventions of external forces", then the role of strategic analysis, in our opinion, is to regular monitoring, testing, diagnostics and evaluation of a combination of diverse and significant factors to ensure the strategic management of the system of timely warning about the need to adopt or correct certain strategies, strategic solutions in order to achieve the company's strategic success. Through strategic analysis, uncertainty 
is significantly reduced, always accompanying projects to develop and implement a strategy.

Regarding the prerequisites of a microeconomic nature that influence the development of the strategic analysis, it can also be noted that the results of the functioning of enterprises is currently a serious problem. This, in particular, is evidenced by the massive nature of bankruptcies of enterprises in the most diverse sectors of the economy. This can only partly be explained by the consequences of the global financial and all-Ukrainian crisis, since the phenomenon of insolvency of enterprises with varying degrees of intensity has been observed throughout the entire period of development of market relations.

Development prerequisites associated with the traditional methodology of economic analysis are in its non-compliance with modern requirements for the evaluation of activities and the performance of enterprises. For the traditional approach to the analysis of indicators of enterprise activity, the concentration is mainly on financial indicators, that is, on indicators reflected in financial statements or calculated on the basis of data presented in financial statements of the company or applications and explanations for it. At the same time, non-financial indicators that have received wide recognition in recent years as the most important signal indicators of the activities of enterprises are not diagnosed. However, «the main performance indicators of companies are not limited to a set of financial indicators. Quality, customer satisfaction, innovation, market share - such criteria often reflect the state of affairs of an enterprise and its growth prospects better than the declared profit». A set of traditionally researched indicators often does not correspond to the most important principle of analysis - the principle of consistency, since the business environment, customers, competitors, components of the value chain remain outside the analytical evaluation. In order to make optimal strategic management decisions, the management of enterprises should, along with external financial reporting, obtain internal strategic-oriented management information that allows them to analyze and evaluate the system of financial and non-financial indicators of the external and internal environment of the enterprise. "A modern company needs a system of indicators 
based on both financial and non-financial information, which takes into account changes in the external environment».

The practice of analyzing the management of enterprises also translates the prerequisites for the development of strategic analysis, which consist in a strategic gap between the need for strategic analysis and the possibilities of its practical implementation on a permanent basis in the company's management system. The specified strategic gap, depending on the factors causing it, can be divided into the following types:

- the methodical gap associated with the fact that the methodic tools of the strategic analysis are not perfect, require development and elaboration of specific practical recommendations;

- institutional gap, manifested in the lack of development of market institutions of information-analytical profile, limiting the ability of the company to use the necessary and reliable information about external conditions.

- the managerial gap, which consists in the static nature of the mentality and conservative thinking of many executives and various levels of management personnel of companies using the old, non-innovative approaches in the new economic conditions;

- financial gap, which consists in the lack of adequate financial resources of the organization, to create its own unit that performs the functions of permanent information and analytical support for the process of strategic management of the company.

Thus, in the conditions of modern Ukrainian realities, along with the prerequisites for stimulating the development of strategic analysis, there are also factors - disincentives that create at this stage certain difficulties in the wide practical application of strategic analysis in the management of enterprises that require finding constructive, relevant and effective ways to overcome them.

Conclusions: Thus, the formed theoretical aspects of strategic analysis of enterprises' competitiveness include the theoretical basis of strategic analysis, methodological provisions, methodological approaches and tools. The indicated components of the concept are depicted in Figure 2, in terms of their constituent elements.

The theoretical provisions of the strategic analysis are based on the decision of generalization of the terminology of strategic 
analysis problems, identification of its essence and content, as well as the identification of the role and place of strategic analysis in the system of strategic management.

Methodological bases of strategic analysis include the substantiation of the concept of strategic analysis of enterprises' competitiveness on the basis of systemic, process, situational, balanced and strategic scientific approaches; as well as a descriptive model of strategic analysis, the principles of strategic analysis, principles of constructing an effective strategically orientated system of indicative evaluation of enterprises, principles of formation of an effective system of information provision of strategic analysis.

Strategic analysis tools integrates a system of strategic analysis methods and a system of indicators of strategic analysis. Methodological provisions of the strategic analysis are based on the methodology for analyzing the strategic climate of enterprises, a methodology for analyzing the strategic potential of enterprises, combining their methodology for analyzing strategic positioning of an enterprise, as well as methods for analyzing strategic gaps that arise in the process of strategic management of an enterprise.

The theoretical aspects of strategic analysis are based on its key role in the process of development and implementation of the enterprises' strategy, which is based on analytical substantiation, analytical support and analytical assessment of the strategy, and in this regard, makes it necessary to implement, in the process of strategic analysis, such modern scientific approaches to management as systemic, procedural, situational, balanced and strategic approaches.

\section{Literature}

1. Grant R. M. Modern strategic analysis. 5th ed., 2008. 560 page.

2. Ambler T. Practical marketing, 1999. - 400 p.

3. Nuzhna O.A., Assessment of the level of competitiveness of agricultural enterprises // Economy of the Agricultural Complex, 2010 - № $4-111$ p.

4. Revutskaya N.V. Strategic resources of the company: modern aspects of identification and evaluation // Economics: 
problems of theory and practice: Collection of scientific works. Issue 263: In 9 t. - T. V. - Dnipropetrovsk: DNU, 2010. - p. 12121216.

5. Nemtsov V.D., Dovgan L.S. Methodology for assessing the level of competitiveness of an enterprise // Economy of the agroindustrial complex. - 2010. - №. 5. - p. 7-9.

6. Parmenter D. Key Performance Indicators: Developing, Implementing, and Using Winning KPI's. - New Jersey, USA: John Wiley \& Sons, Inc. - 2007.

7. Thompson A.A., Strickland A.J. Strategic Management: Concepts and Situations for Analysis. - 12th ed. - 2005.

20.09.2018

УДК 657.1:656

JEL Classification: L910; M420

Слободяник Юлія

\section{ОСОБЛИВОСТІ КОНТРОЛЮ ДОХОДІВ ПІДПРИЕМСТВ МІСЬКОГО ПАСАЖИРСЬКОГО ТРАНСПОРТУ}

Розкрито специфіку функціонування підприємств міського пасажирського транспорту на сучасному етапі. Визначено, що ефективність їх діяльності підтримує соціальноекономічний розвиток території. Виявлено, що в Україні підприємства міського пасажирського транспорту переживають глибоку кризу, що проявляється у недостатності фінансових ресурсів, неспроможності підтримання стабільної роботи, старінні рухомого складу, погіршенні якості обслуговування населення. Обгрунтовано важливість оцінки достовірності доходів підприємств міського пасажирського транспорту. Проаналізовано порядок формування доходів комунальних підприємств міського пасажирського транспорту, визначено їх структуру. Аргументовано, що для забезпечення соціальної 
функції галузі доцільно застосування регульованих тарифів, які мають бути економічно виправданими. Досліджено проблему 